\title{
Erratum to: Isoproterenol Cytotoxicity is Dependent on the Differentiation State of the Cardiomyoblast H9c2 Cell Line
}

\author{
Ana F. Branco $\cdot$ Sandro L. Pereira $\cdot$ \\ Ana C. Moreira · Jon Holy • Vilma A. Sardão • \\ Paulo J. Oliveira
}

Published online: 21 July 2011

(C) Springer Science+Business Media, LLC 2011

\section{Erratum to: Cardiovasc Toxicol}

DOI 10.1007/s12012-011-9111-5

In the original publication, the parenthetical phrase "See companion paper" (which appears in the last lines of first and second pages and, on page 11, in line 3 of the first column and line 21 of the second column) should instead read: Pereira, S.L., Ramalho-Santos, J., Branco, A.F., Sardão, V.A., Oliveira, P.J., Carvalho, R.A. Metabolic remodeling during $\mathrm{H} 9 \mathrm{c} 2$ myoblast differentiation: relevance for in vitro toxicity studies. Cardiovascular Toxicology, 11(2), 180-90.

The online version of the original article can be found under doi: 10.1007/s12012-011-9111-5.

A. F. Branco - S. L. Pereira - A. C. Moreira .

V. A. Sardão · P. J. Oliveira $(\square)$

Center for Neuroscience and Cell Biology, Department of Life

Sciences, University of Coimbra, 3004-517 Coimbra, Portugal

e-mail: pauloliv@ci.uc.pt

J. Holy

Department of Anatomy, Microbiology and Pathology,

University of Minnesota Medical School, Duluth, MN, USA 